\title{
Inhibition of Insulin-Stimulated Xylose Uptake in Denervated Rat Soleus Muscle: a Post-receptor Effect
}

\author{
J.R. Forsayeth and M. K. Gould \\ Department of Biochemistry, Monash University, Clayton, Victoria, Australia
}

\begin{abstract}
Summary. Insulin (100 U/1) stimulated xylose uptake in rat soleus muscle from a basal value of $2.3 \pm 0.5$ to $11.6 \pm 2.1$ umol $\cdot \mathrm{g}^{-1} \cdot \mathrm{h}^{-1}$. Denervation (section of the sciatic nerve) markedly reduced the stimulatory action of insulin (basal 1.3 $\pm 0.4 \mu \mathrm{mol} \cdot \mathrm{g}^{-1} \cdot \mathrm{h}^{-1}$; insulin-stimulated $4.5 \pm 0.6 \mu \mathrm{mol}$. $\left.\mathrm{g}^{-1} \cdot \mathrm{h}^{-1}\right)$. This effect appeared 3 days after denervation and was maximal after 5 days. Denervation also affected the insulin dose response curve; there was no effect of insulin in denervated muscle until the concentration exceeded $1 \mathrm{U} / 1$. Denervation inhibited insulin-stimulated $\alpha$-aminoisobutyrate uptake by $77 \%$ but did not affect ${ }^{125}$ I-insulin binding or glucose-independent activation of glycogen synthase by insulin. There was no effect of denervation on the insulinomimetic ef-
\end{abstract}

fects of concanavalin A, hydrogen peroxide, vitamin $\mathrm{K}_{5}$, anoxia, 2:4-dinitrophenol, cooling, hyperosmolarity or EDTA, but the effect of diamide was inhibited. It is concluded [1] that denervation inhibits insulin-stimulated sugar transport at some early post-receptor step, and [2] that the mechanism whereby insulin activates glycogen synthase is different from the activation of the membrane transport of sugars and amino acids.

Key words: Denervation, insulin-resistance, sugar transport, amino acid transport, glycogen synthase, ${ }^{125} \mathrm{I}$-insulin binding, concanavalin A, diamide.
Considerable progress has been made in recent years concerning the interaction between insulin and its receptor $[1,2]$. More recently, it has been suggested that insulin stimulates sugar transport by promoting the translocation of sugar carriers from intracellular sites to the plasma membrane $[3,4]$. However, the nature of the signalling mechanism which couples the insulin receptor to the sugar transport system remains obscure. It has been demonstrated that insulin induces the release of a chemical messenger from the plasma membrane which mediates the effect of the hormone on the intracellular enzymes, glycogen synthase and pyruvate dehydrogenase [5-7]. This factor has not yet been associated with insulin-stimulated sugar transport.

The coupling system can be studied using agents which block insulin action at the post-receptor level. Buse and Buse [8] reported that denervation (section of the phrenic nerve) abolished the stimulatory effect of insulin on glucose uptake by rat hemidiaphragm. They found that denervation inhibited insulin-stimulated Dxylose uptake by diaphragm in vitro and in vivo [9]. Denervation did not affect total $\left[{ }^{131} \mathrm{I}\right] \mathrm{insulin}$ binding by diaphragm in vitro and in vivo [8], which suggests that the insulin-resistant state induced by denervation is due to some post-receptor lesion. The nature of this defect does not appear to have been further studied. The experiments reported in this study were designed to observe the effects of denervation on insulin-stimulated muscle sugar transport in rat soleus muscle.

\section{Methods}

Soleus muscles were removed from denervated and control rats $(50-60 \mathrm{~g})$. Muscles were incubated at $37^{\circ} \mathrm{C}$ (unless otherwise stated) under an atmosphere of $\mathrm{O}_{2}-\mathrm{CO}_{2}(95: 5, \mathrm{v} / \mathrm{v})$; anaerobic incubations were under $\mathrm{N}_{2}-\mathrm{CO}_{2}(95: 5, \mathrm{v} / \mathrm{v})$. The basic ('bicarbonate') medium contained $\mathrm{NaCl}(118 \mathrm{mmol} / \mathrm{l}), \mathrm{KCl}(4.8 \mathrm{mmol} / \mathrm{l}), \mathrm{CaCl}_{2}(2.6 \mathrm{mmol} / 1)$, $\mathrm{MgSO}_{4}(1.2 \mathrm{mmol} / 1), \mathrm{KH}_{2} \mathrm{PO}_{4}(1.2 \mathrm{mmol} / \mathrm{l})$ and $\mathrm{NaHCO}_{3}(25 \mathrm{mmol} /$ 1); before use the medium was gassed with the appropriate gas mixture. Additions to, or variations from, this basic medium are detailed in the text.

\section{Sugar Transport}

Xylose uptake was determined using the method of Korbl et al. [10]. In this procedure the muscles are first preincubated in $0.5 \mathrm{ml}$ of bicarbonate medium under the test conditions; the uptake of $\mathrm{D}-\left[\mathrm{U}-{ }^{14} \mathrm{C}\right]$ xylose (final concentration $10 \mathrm{mmol} / 1$, specific activity $0.03 \mu \mathrm{Ci}$ / $\mu \mathrm{mol})$ is then measured over a $5 \mathrm{~min}$ period, using $\mathrm{D}-\left[1{ }^{\left.-{ }^{3} \mathrm{H}\right]}\right.$ sorbitol $(10 \mathrm{mmol} / 1$, specific activity $0.1 \mu \mathrm{Ci} / \mu \mathrm{mol})$ as the extracellular marker. 


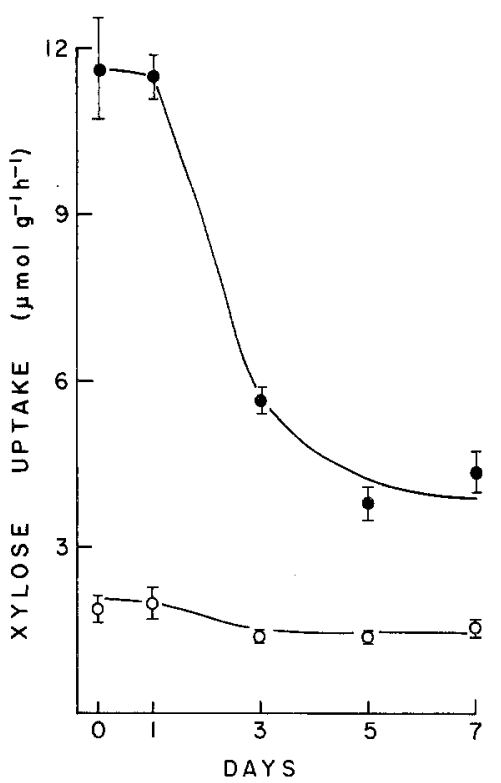

Fig. 1. Effect of denervation on basal and insulin-stimulated xylose uptake. Soleus muscles were taken from rats before and up to 7 days after denervation. Muscles were incubated first for $30 \mathrm{~min}$ at $37^{\circ} \mathrm{C}$ in bicarbonate medium and then for $30 \mathrm{~min}$ in the presence $(\boldsymbol{\theta})$ or absence $(O)$ of insulin $(100 \mathrm{U} / 1)$. Each point is the mean \pm SEM of five determinations

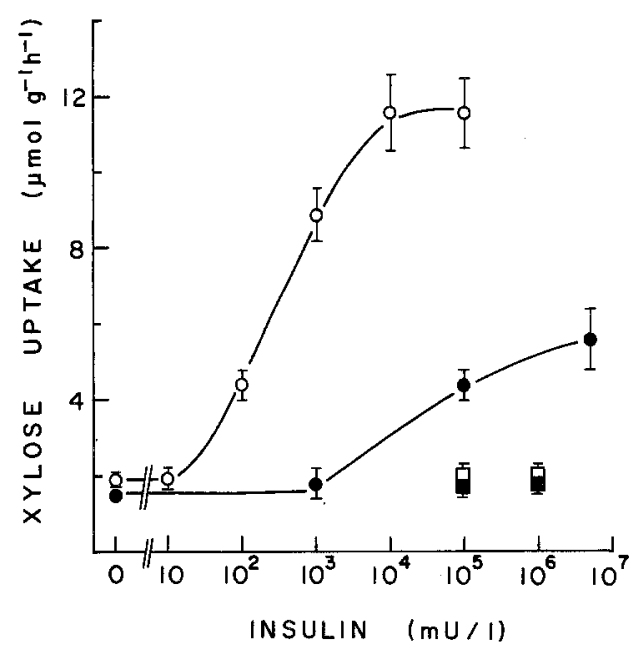

Fig. 2. Effect of denervation on the insulin dose response curve. Muscles from either normal $(O)$ or 7-day denervated $(0)$ rats were incubated first for $15 \mathrm{~min}$ at $37^{\circ} \mathrm{C}$ in bicarbonate medium and then for a further $15 \mathrm{~min}$ in the presence or absence of insulin $\left(10-5 \times 10^{6} \mathrm{mU} / 1\right)$. The square symbols indicate control experiments where normal ( $\square$ ) and denervated ( $)$ muscles were incubated with deactivated insulin. Each point is the mean \pm SEM of five determinations

\section{${ }^{125}$ I-insulin Binding}

Beef insulin was iodinated using carrier-free sodium $\left[{ }^{125}\right.$ I]iodide and cloramine $T$ according to the method of Greenwood et al. [11]. Labelled insulin was separated by chromatography on Sephadex G-50. The purity of each fraction was checked by paper electrophoresis; only those fractions in which at least $95 \%$ of total ${ }^{125} \mathrm{I}$ was present as ${ }^{125} \mathrm{I}$ insulin were used. ${ }^{125} \mathrm{I}$-insulin binding to soleus muscle was measured using the procedure developed by $\mathrm{Yu}$ and Gould [12]. Soleus muscle pairs were incubated for $90 \mathrm{~min}$ at $25^{\circ} \mathrm{C}$ in $1 \mathrm{ml}$ of bicarbonate medium containing bovine serum albumin $(2 \mathrm{mg})$ and ${ }^{125} \mathrm{I}$-insulin
$(0.17 \mathrm{nmol} / 1$, specific activity $25-50 \mathrm{Ci} / \mathrm{g}$, equivalent to $0.07-0.14$ atoms ${ }^{125} \mathrm{I} / \mathrm{mol}$ insulin) \pm unlabelled insulin (up to $3.3 \mu \mathrm{mol} / 1$ ). The muscles were washed twice at $0^{\circ} \mathrm{C}$ in $5 \mathrm{ml}$ of bicarbonate buffer, first for $30 \mathrm{~min}$, then for $60 \mathrm{~min}$, then homogenized in $2 \mathrm{ml}$ of trichloroacetic acid $(50 \mathrm{~g} / 1)$. The homogenizer was rinsed twice with $2 \mathrm{ml}$ of trichloroacetic acid $(50 \mathrm{~g} / 1)$; the combined homogenate and rinsings were filtered through a $2.5 \mathrm{~cm}$ Whatman GF/A glass fibre disc in a Millipore filter. The precipitate on the filter was washed three times, each with $5 \mathrm{ml}$ of ice-cold trichloroacetic acid $(50 \mathrm{~g} / \mathrm{l})$, then counted in a Philips PW 4520 gamma counter. Specific ${ }^{125} \mathrm{I}$-insulin binding was calculated as the difference between ${ }^{125}$ I-insulin bound in the presence of tracer alone ('total binding') and in the presence of tracer plus $3.3 \mu \mathrm{mol}$ unlabelled insulin/1 ('non-specific binding').

\section{Amino Acid Transport}

Uptake of $\alpha$-aminoisobutyrate was assayed by incubating muscles for $15 \mathrm{~min}$ in $0.5 \mathrm{ml}$ of bicarbonate buffer containing $1 \mathrm{mmol} / 1 \alpha-\left[1-{ }^{14} \mathrm{C}\right]$ aminoisobutyrate (specific activity $0.05 \mu \mathrm{Ci} / \mu \mathrm{mol}$ ) and $10 \mathrm{mmol} / 1 \mathrm{D}$ $\left[1-{ }^{3} \mathrm{H}\right]$ sorbitol (specific activity $0.5 \mu \mathrm{Ci} / \mu \mathrm{mol}$ ) as an extracellular marker. The muscles were dissolved in NCS tissue solubilizer and counted in a similar manner to those used for the determination of xylose uptake.

\section{Glycogen Synthase}

Following the appropriate incubation, the muscles were frozen in liquid nitrogen and held at $-70^{\circ} \mathrm{C}$. Each muscle was added to $0.2 \mathrm{ml}$ of a solution containing Tris- $\mathrm{HCl}$ buffer $(10 \mathrm{mmol} / \mathrm{l}, \mathrm{pH} 7.8)$, EDTA $(10 \mathrm{mmol} / 1), \mathrm{NaF}(50 \mathrm{mmol} / 1)$ and glycerol $(600 \mathrm{ml} / \mathrm{l})$ in a small glass homogenizer (internal diameter $8 \mathrm{~mm}$ ) pre-frozen in liquid nitrogen. The frozen muscle and buffer were crushed together into a powder using the Teflon pestle manually. To this mixture was added $0.6 \mathrm{ml}$ of a solution containing Tris- $\mathrm{HCl}$ buffer $(10 \mathrm{mmol} / 1, \mathrm{pH} 7.8)$, EDTA $(5 \mathrm{mmol} / \mathrm{l}), \mathrm{NaF}(50 \mathrm{mmol} / \mathrm{l})$, mercaptoethanol $(50 \mathrm{mmol} / \mathrm{l})$ and bovine serum albumin $(1 \mathrm{~g} / 1)$. The contents of the tube were allowed to warm to $0^{\circ} \mathrm{C}$ in an ice bath, whereupon they were homogenized for $20-25 \mathrm{~s}$ to achieve an even homogenate. This was transferred to a plastic tube and centrifuged in an Eppendorf 5412 microfuge for 5 min. The supernatant solution was applied to a Sephadex G-25 column (Pharmacia, PD-10) equilibrated with Tris-HCl buffer (10 $\mathrm{mmol} / \mathrm{l}, \mathrm{pH} 7.8)$ containing EDTA $(5 \mathrm{mmol} / 1), \mathrm{NaF}(50 \mathrm{mmol} / \mathrm{l})$ and mercaptoethanol $(50 \mathrm{mmol} / 1)$. The column was developed with the same buffer. The elution of the protein peak was monitored using the Coomassie blue reagent described by Bradford [13]; the protein-containing fractions were pooled. Glycogen synthase was assayed using the method of Thomas et al. [14]. The percentage of synthase in the active, I form was determined by assaying the enzyme in the absence (synthase I) and presence (total synthase I + D) of $20 \mathrm{mmol}$ glucose6-phosphate/l.

\section{Denervation}

Sprague-Dawley rats weighing $50-60 \mathrm{~g}$ were anaesthetized with ether. After treating the area with a solution of hibitane $(5 \mathrm{ml}$ hibitane, $10 \mathrm{ml}$ water, $85 \mathrm{ml}$ absolute ethanol), a small incision was made in the skin on the lateral aspect of each thigh and the sciatic nerve exposed. A section of nerve approximately $5 \mathrm{~mm}$ in length was removed and the wound closed with Michel clips. The animals were held for up to 7 days before further experimentation. Muscles taken from rats (50-60 g) at the time of operation weigh $20-25 \mathrm{mg}$; muscles from normal rats $(70-90 \mathrm{~g})$ one week later weigh $30-35 \mathrm{mg}$. Following denervation, muscles do not increase in mass; 1 week later they still weigh $20-25 \mathrm{mg}$. Basal xylose uptake in normal $20-25 \mathrm{mg}$ muscles was determined to be $2.6 \pm 0.1 \mu \mathrm{mol} \cdot \mathrm{g}^{-1} \cdot \mathrm{h}^{-1}(n=9)$ and in normal $30-35 \mathrm{mg}$ muscles taken from litter-mates one week later $3.0 \pm$ $0.2 \mu \mathrm{mol} \cdot \mathrm{g}^{-1} \cdot \mathrm{h}^{-1}(n=9$; NS). Accordingly, control muscles were taken from $50-60 \mathrm{~g}$ rats so that their weight would be the same as the denervated muscles. 


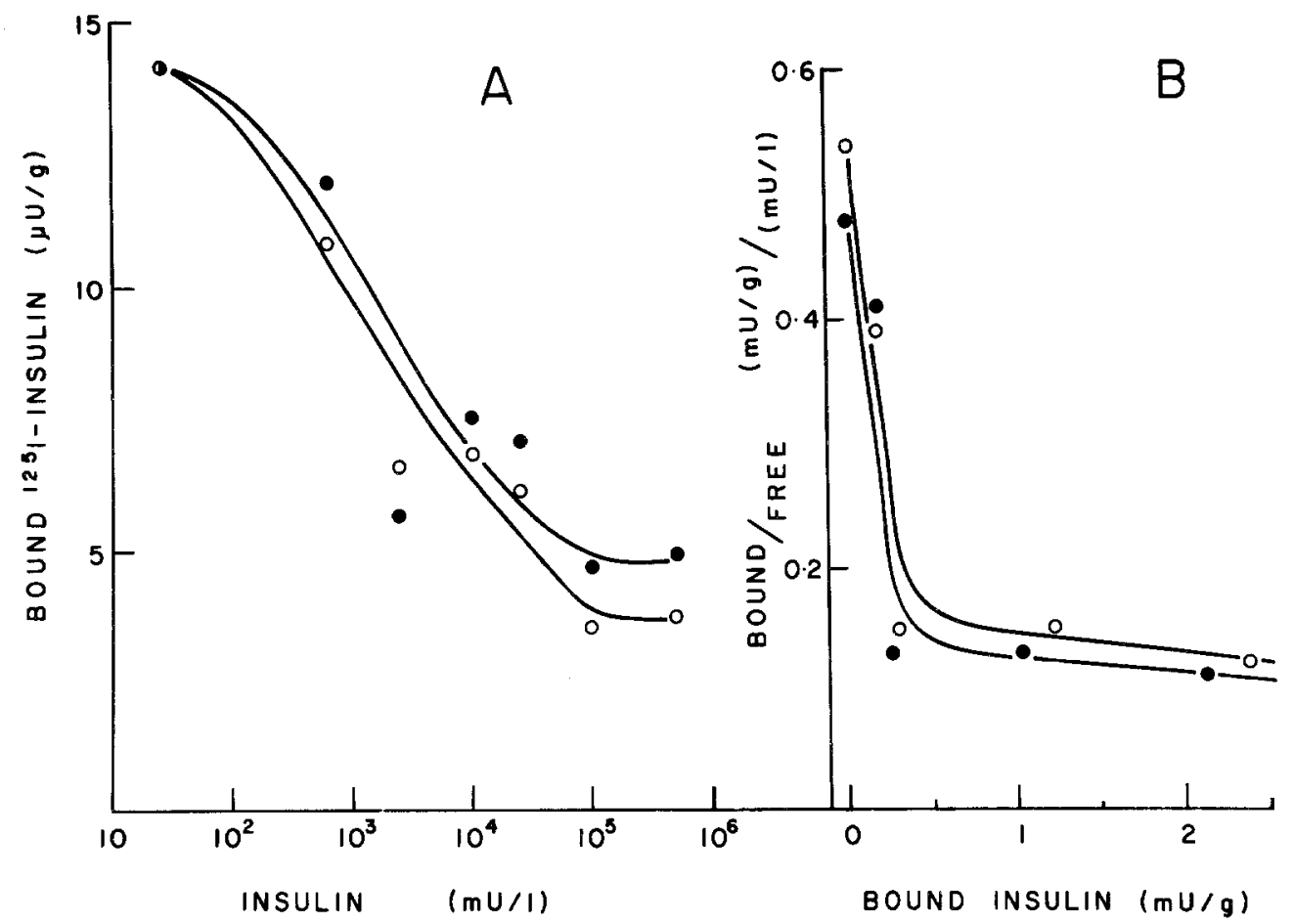

Fig. 3 A and B. ${ }^{125} \mathrm{I}$-insulin binding by normal and denervated soleus muscle. A Muscles were incubated for 90 min at $25^{\circ} \mathrm{C}$ in the presence of ${ }^{125} \mathrm{I}$ insulin $(0.17 \mathrm{nmol} / 1)$ and various concentrations of unlabelled insulin (up to $3.3 \mu \mathrm{mol} / \mathrm{l}$ ). B Scatchard plots derived from the data shown in $\mathrm{A}$. $\mathrm{O}=$ normal muscle, $\mathbf{O}=$ denervated muscle. Each point is the mean of ten determinations

Table 1. Effect of denervation on insulin stimulation of amino acid transport and glycogen synthase in rat soleus muscle

\begin{tabular}{llll}
\hline & $\begin{array}{l}\text { Dener- } \\
\text { vated }\end{array}$ & Basal & Insulin \\
\hline $\begin{array}{llll}\alpha \text {-Aminoisobutyrate } \\
\text { uptake }\end{array}$ & - & $0.77 \pm 0.24(5)$ & $1.67 \pm 0.12(5)^{\mathrm{b}}$ \\
$\left(\mu \mathrm{mol} \cdot \mathrm{g}^{-1} \cdot \mathrm{h}^{-1}\right)$ & + & $0.84 \pm 0.07(5)$ & $1.05 \pm 0.07(5)^{\mathrm{a}}$ \\
$\begin{array}{l}\text { Glycogen synthase } \\
(\% \text { synthase I) }\end{array}$ & - & $15.0 \pm 0.7(4)$ & $20.9 \pm 1.9(4)^{\mathrm{c}}$ \\
\hline
\end{tabular}

$\alpha$-aminoisobutyrate uptake: soleus muscle pairs were incubated for $30 \mathrm{~min}$ at $37^{\circ} \mathrm{C}$ in bicarbonate medium \pm insulin $(100 \mathrm{U} / 1)$; the uptake of $\alpha-\left[1-{ }^{14} \mathrm{C}\right]$ aminoisobutyrate was then determined as detailed under Methods. Glycogen synthase: soleus muscle pairs were preincubated for 30 min at $37^{\circ} \mathrm{C}$ in bicarbonate medium; insulin (100 U/l) was added to one muscle from each pair and the muscles incubated a further $15 \mathrm{~min}$.

Results are expressed as mean \pm SEM with number of determinations in parentheses. Insulin versus basal: ${ }^{\mathrm{a}}=p<0.01{ }^{\mathrm{b}}=$ $p<0.005,{ }^{c}=p<0.001$

\section{Materials}

D-[U- $\left.{ }^{14} \mathrm{C}\right] \mathrm{xylose}$, sodium $\left[{ }^{125}\right.$ I]iodide and NCS tissue solubilizer were from Amersham Australia Pty., Sydney, Australia. D- $\left[1-{ }^{3} \mathrm{H}\right]$ sorbitol and $\alpha-\left[1-{ }^{14} \mathrm{C}\right]$-aminoisobutyrate were from New England Nuclear Corporation, Boston, USA. Beef insulin, twice recrystallized, was from the Commonwealth Serum Laboratories, Melbourne, Australia. A sample of insulin was deactivated by heating a solution containing insulin $(4 \mathrm{~g} / 1)$, urea $(6 \mathrm{~mol} / 1)$ and dithiothreitol $(13 \mathrm{mmol} / 1), \mathrm{pH} 3.0$, for $30 \mathrm{~min}$ at $60^{\circ} \mathrm{C}$, then neutralizing to $\mathrm{pH} 7.0 .2: 4$-dinitrophenol and EDTA were from British Drug House Chemicals Australia, Sydney. Concanavalin A was from Boehringer-Mannheim (Australia), Sydney. Mannitol was from Calbiochem-Behring (Australia), Sydney. Vi- tamin $\mathrm{K}_{5}$ was from Tokyo Kasei Kogyo, Tokyo. $\alpha$-aminoisobutyrate, diamide, dithiothreitol and rabbit liver glycogen were from Sigma Chemicals, St. Louis, USA.

\section{Statistics}

To minimise the effect of biological variation between individual animals, wherever possible the experiments were designed using paired controls. One muscle from each pair was incubated under test conditions, while the second served as the control. The results of these experiments were analyzed for statistical significance using Student's t-test as applied to paired samples. Where it was not possible to use paired controls, muscles taken from litter-mates were distributed randomly among the experimental groups and the results subjected to statistical analysis using the standard Student's t-test.

\section{Results}

In normal muscle, insulin $(100 \mathrm{U} / 1)$ stimulates xylose uptake by $510 \%$ (from a basal value of $2.3 \pm 0.5$ to 11.6 $\pm 2.1 \mu \mathrm{mol} \cdot \mathrm{g}^{-1} \cdot \mathrm{h}^{-1}(n=5, p<0.001)$. Following denervation the stimulatory effect of insulin was markedly reduced (Fig.1). The effect of denervation was apparent after 3 days and became maximal after 5 days. Denervation did not abolish insulin action completely; in denervated muscle (5 days) insulin stimulated xylose uptake by only $170 \%$ (from a basal value of $1.3 \pm 0.4$ to $4.5 \pm 0.6 \mu \mathrm{mol} \cdot \mathrm{g}^{-1} \cdot \mathrm{h}^{-1}, n=5, p<0.02$ ).

The effect of denervation on the insulin dose response curve is shown in Figure 2. In normal muscle the effect of insulin becomes apparent above $10 \mathrm{mU} / 1$ and is maximal at $10 \mathrm{U} / 1$. In contrast, there was no effect in 
Table 2. Effect of denervation on activators of muscle sugar transport in rat soleus muscle

\begin{tabular}{|c|c|c|c|c|c|}
\hline \multirow[t]{2}{*}{ Activator } & \multirow{2}{*}{$\begin{array}{l}\text { Period of exposure } \\
\text { to activator } \\
\text { (min) }\end{array}$} & & \multicolumn{2}{|c|}{ Xylose uptake $\left(\mu \mathrm{mol} \cdot \mathrm{g}^{-1} \cdot \mathrm{h}^{-1}\right)$} & \multirow{2}{*}{$\begin{array}{l}\text { Stimula- } \\
\text { tion } \\
(\%)\end{array}$} \\
\hline & & & Basal & Activated & \\
\hline Xylose $(30 \mathrm{mmol} / 1)$ & $0^{\mathrm{a}}$ & $\begin{array}{l}\text { normal } \\
\text { denervated }\end{array}$ & $\begin{array}{l}2.2 \pm 0.2 \\
2.6 \pm 0.5\end{array}$ & $\begin{array}{r}7.9 \pm 0.8^{\mathrm{g}} \\
10.4 \pm 3.2^{\mathrm{g}}\end{array}$ & $\begin{array}{l}259 \\
300\end{array}$ \\
\hline Concanavalin A $(500 \mathrm{mg} / \mathrm{l})$ & 30 & $\begin{array}{l}\text { normal } \\
\text { denervated }\end{array}$ & $\begin{array}{l}2.3 \pm 0.4 \\
1.9 \pm 0.1\end{array}$ & $\begin{array}{l}6.0 \pm 0.2^{\mathrm{f}} \\
4.5 \pm 0.3^{\mathrm{f}}\end{array}$ & $\begin{array}{l}161 \\
137\end{array}$ \\
\hline Diamide $(0.15 \mathrm{mmol} / 1)$ & 30 & $\begin{array}{l}\text { normal } \\
\text { denervated }\end{array}$ & $\begin{array}{l}2.5 \pm 0.2 \\
2.1 \pm 0.2\end{array}$ & $\begin{array}{l}6.5 \pm 0.6^{\mathrm{g}} \\
3.2 \pm 0.4^{d}\end{array}$ & $\begin{array}{r}160 \\
52\end{array}$ \\
\hline $\mathrm{H}_{2} \mathrm{O}_{2}(1 \mathrm{mmol} / \mathrm{l})$ & 10 & $\begin{array}{l}\text { normal } \\
\text { denervated }\end{array}$ & $\begin{array}{l}2.4 \pm 0.1 \\
2.4 \pm 0.2\end{array}$ & $\begin{array}{l}5.8 \pm 0.2^{\mathrm{g}} \\
5.4 \pm 0.3^{\mathrm{g}}\end{array}$ & $\begin{array}{l}142 \\
125\end{array}$ \\
\hline Vitamin $K_{5}(100 \mu \mathrm{mol} / 1)$ & 30 & $\begin{array}{l}\text { normal } \\
\text { denervated }\end{array}$ & $\begin{array}{l}2.0 \pm 0.1 \\
2.3 \pm 0.3\end{array}$ & $\begin{array}{l}5.5 \pm 0.5^{\mathrm{g}} \\
6.4 \pm 0.3^{\mathrm{g}}\end{array}$ & $\begin{array}{l}175 \\
178\end{array}$ \\
\hline Anoxia & $\mathrm{b}$ & $\begin{array}{l}\text { normal } \\
\text { denervated }\end{array}$ & $\begin{array}{l}2.0 \pm 0.3 \\
1.6 \pm 0.2\end{array}$ & $\begin{array}{l}7.0 \pm 0.4^{\mathrm{f}} \\
5.4 \pm 0.3^{\mathrm{g}}\end{array}$ & $\begin{array}{l}250 \\
238\end{array}$ \\
\hline 2:4-Dinitrophenol $(0.5 \mathrm{mmol} / \mathrm{l})$ & 10 & $\begin{array}{l}\text { normal } \\
\text { denervated }\end{array}$ & $\begin{array}{l}2.4 \pm 0.2 \\
1.8 \pm 0.2\end{array}$ & $\begin{array}{l}7.1 \pm 0.6^{\mathrm{f}} \\
5.6 \pm 0.5^{\mathrm{f}}\end{array}$ & $\begin{array}{l}196 \\
211\end{array}$ \\
\hline Cooling & $\mathrm{c}^{\mathrm{c}}$ & $\begin{array}{l}\text { normal } \\
\text { denervated }\end{array}$ & $\begin{array}{l}2.4 \pm 0.3 \\
2.1 \pm 0.1\end{array}$ & $\begin{array}{l}6.1 \pm 0.2^{\mathrm{g}} \\
5.7 \pm 0.2^{\mathrm{g}}\end{array}$ & $\begin{array}{l}154 \\
171\end{array}$ \\
\hline Mannitol $(200 \mathrm{mmol} / \mathrm{l})$ & 30 & $\begin{array}{l}\text { normal } \\
\text { denervated }\end{array}$ & $\begin{array}{l}2.2 \pm 0.4 \\
1.6 \pm 0.2\end{array}$ & $\begin{array}{l}7.5 \pm 0.7^{\mathrm{e}} \\
5.7 \pm 0.1^{\mathrm{g}}\end{array}$ & $\begin{array}{l}241 \\
256\end{array}$ \\
\hline EDTA $(5 \mathrm{mmol} / 1)$ & 5 & $\begin{array}{l}\text { normal } \\
\text { denervated }\end{array}$ & $\begin{array}{l}2.4 \pm 0.2 \\
2.1 \pm 0.1\end{array}$ & $\begin{array}{l}5.3 \pm 0.4^{\mathrm{g}} \\
5.8 \pm 0.2^{\mathrm{f}}\end{array}$ & $\begin{array}{l}121 \\
176\end{array}$ \\
\hline
\end{tabular}

Results are expressed as mean \pm SEM of five to seven determinations.

With the exceptions noted below, soleus muscle pairs were preincubated for $30 \mathrm{~min}$ at $37^{\circ} \mathrm{C}$ under aerobic conditions. At this point the agents shown were added to one muscle and the incubation continued for the times shown in the second column.

a $30 \mathrm{mmol} / 1$ xylose was added to one muscle together with the radioactive test sugars. To avoid complication due to the effect of hyperosmolarity, an equivalent amount of $\mathrm{NaCl}$ was omitted from the medium; ${ }^{\mathrm{b}}$ Muscles were preincubated for 60 min at $37^{\circ} \mathrm{C}$ under either $95 \% \mathrm{O}_{2}-5 \% \mathrm{CO}_{2}$ or $95 \% \mathrm{~N}_{2}-5 \% \mathrm{CO}_{2} ;{ }^{\circ}$ Muscle pairs were preincubated for $30 \mathrm{~min}$ at $37^{\circ} \mathrm{C}$; one muscle from each pair was then incubated for $3 \mathrm{~h}$ at $0{ }^{\circ} \mathrm{C}$. Xylose uptake was measured at $37^{\circ} \mathrm{C}$.

Activated versus basal: ${ }^{\mathrm{d}} p<0.05 ;^{\mathrm{e}} p<0.01 ;{ }^{\mathrm{f}} p<0.005 ; \mathrm{g} p<0.001$

denervated muscle until the insulin concentration exceeded $1 \mathrm{U} / 1$. Insulin, de-activated by exposure to urea and dithiothreitol (see Methods), was without effect on xylose transport in normal or denervated muscles. Control experiments, where muscles were exposed to the same concentration of urea and dithiothreitol as present in the deactivated insulin, established that these agents did not affect either basal or insulin-stimulated sugar transport.

The experiment shown in Figure 3 examined ${ }^{125} \mathrm{I}$-insulin binding by normal and denervated soleus muscle. Muscles were incubated for $90 \mathrm{~min}$ at $25^{\circ} \mathrm{C}$ in the presence of ${ }^{125} \mathrm{I}$-insulin $(0.17 \mathrm{nmol} / \mathrm{l})$ and various concentrations of unlabelled insulin (up to $3.3 \mu \mathrm{mol} / 1$ ). The competitive binding curves thus obtained are shown in Figure $3 \mathrm{~A}$ and the Scatchard plots derived therefrom are shown in Figure 3 B. Denervation did not affect ${ }^{125} \mathrm{I}$ insulin binding. Specific ${ }^{125} \mathrm{I}$-insulin binding, calculated from the binding values at $0.17 \mathrm{nmol} / 1$, was $73 \pm 5 \mathrm{fmol}$ ${ }^{125} \mathrm{I}$-insulin bound/g normal muscle and $65 \pm 4 \mathrm{fmol}$ ${ }^{125} \mathrm{I}$-insulin bound/g denervated muscle ( $n=10$, NS).

Denervation has variously been reported both to stimulate and to depress the uptake of the amino acid analogue, $\alpha$-aminoisobutyrate, by muscle $[15,16]$. We found that denervation did not affect basal $\alpha$-aminoiso- butyrate uptake in soleus muscle (Table 1). However, the stimulatory effect of insulin on $\alpha$-aminoisobutyrate uptake was reduced from $117 \%$ in normal muscle to $25 \%$ in denervated muscle. We also examined glucoseindependent activation of glycogen synthase by insulin in normal and denervated muscle. The total activity of glycogen synthase, measured in the presence of $20 \mathrm{mmol}$ glucose-6-phosphate/ 1 was reduced from 0.63 $\pm 0.03 \mathrm{U} / \mathrm{g}$ muscle $(n=6)$ in normal muscle to $0.40 \pm$ $0.05 \mathrm{U} / \mathrm{g}(n=6)$ in denervated muscle. Nevertheless, the percentage of glycogen synthase in the active form was the same in both muscle groups following incubation under basal conditions, or in the presence of insulin (Table 1).

To define more precisely the nature of the defect involved, we examined the effect of denervation on the action of a number of other agents which have been shown to stimulate sugar transport. Apart from increasing the concentration of xylose itself, the other agents used for these experiments were concanavalin A [17-19], the oxidants, diamide, $\mathrm{H}_{2} \mathrm{O}_{2}$ and vitamin $\mathrm{K}_{5}$ $[20,21]$, anoxia and 2:4-dinitrophenol [10], cooling [22], hyperosmolarity (200 mmol mannitol/1) [23] and EDTA [24]. The natural variation between groups of rats tends to complicate any comparison between nor- 
mal and denervated muscles in terms of absolute uptake rates. A more suitable basis for comparison is the percentage stimulation achieved in each group. Denervation did not affect the ability of the sugar transport system to respond when the concentration of xylose was increased from 10 to $40 \mathrm{mmol} / 1$ (Table 2). Similarly, denervation did not suppress the stimulatory effects of concanavalin $\mathrm{A}, \mathrm{H}_{2} \mathrm{O}_{2}$, vitamin $\mathrm{K}_{5}$, anoxia, 2:4-dinitrophenol, cooling, hyperosmolarity or EDTA. Denervation reduced the stimulatory effect of diamide from $160 \%$ in normal muscle to $52 \%$ in denervated muscle.

\section{Discussion}

From the observed effects of denervation on insulinstimulated sugar transport in diaphragm, Buse and Buse [9] concluded that insulin-sensitivity was governed by the activity of the muscle. Support for this theory comes from more recent studies showing that glucose tolerance is impaired in bedridden patients [25] and in patients with spinal cord injuries [26] and is improved by a programme of exercise training [27].

The studies reported in this paper confirm and extend the earlier observations of Buse and Buse $[8,9]$. Whereas they found that denervation abolished insulin action in the diaphragm, our experiments have shown that denervation does not abolish the action of insulin on sugar transport, but rather induces a massive resistance to the hormone. The apparent contradiction between the effect of denervation on diaphragm and soleus muscle is easily explained in terms of the insulin concentration used by Buse and Buse (1 U/I). We also found that there was no effect of $1 \mathrm{U}$ insulin $/ 1$ on sugar transport in denervated soleus muscle; it was only when higher concentrations of insulin were used that denervated muscle showed any response to the hormone.

Perhaps one of the most important facts to emerge from the studies of Buse and Buse [8] was that denervation did not affect the ability of the muscle to bind ${ }^{131} \mathrm{I}$ insulin, thus localizing the defect to the post-receptor action of the hormone. However, because their work predated the current practice of measuring specific (i.e. displaceable) as distinct from non-specific (non-displaceable) insulin binding, their values would have included both specifically- and non-specifically-bound insulin. Using a method which differentiates between specific and non-specific binding, we have confirmed that denervation does not affect specific binding of ${ }^{125} \mathrm{I}$ insulin by soleus muscle.

Denervation inhibited the stimulatory effect of insulin on amino acid transport to the same extent as its inhibition of insulin-stimulated sugar transport (Table 1; [15]). Conversely, the ability of insulin to activate glycogen synthase (by the glucose-independent mechanism) was unaffected by denervation. This, together with the ${ }^{125} \mathrm{I}$-insulin binding data, indicate that the mechanism whereby insulin binds to its receptor and generates an intracellular mediator [5] is not impaired in denervated muscle. Thus, the mechanism concerned with the activation of the intracellular enzyme, glycogen synthase, differs from that involved in the activation of the two membrane transport systems. Dissociation between insulin's action on membrane systems and intracellular enzyme systems can also be demonstrated using puromycin [28], N-ethylmaleimide [29] and neuraminidase [30]. The action of insulin on intracellular enzyme systems is believed to be effected through the release of a low-molecular-weight mediator protein from the plasma membrane [5-7]. The fact that insulin's intracellular actions can be dissociated from its effect on membrane transport systems could suggest, prima facie, that those actions of insulin which involve membrane-localized systems are mediated through some mechanism other than the 'intracellular' messenger.

Because denervation inhibits insulin-stimulated sugar transport at the post-receptor level, it can serve as a probe to examine the coupling of the insulin receptor to the sugar transport system. Nine of the ten insulinomimetic agents shown in Table 2 were still able to activate sugar transport in denervated muscle to the same extent as in normal muscle. This suggests that the defect in denervated muscle is at some early post-receptor step. Two of the results in Table 2 deserve further comment: first, the insensitivity to denervation of the stimulatory effect of concanavalin A. Concanavalin A is one of a number of plant lectins which has been shown to stimulate glucose transport in adipocytes $[17,18]$; to our knowledge the effect of concanavalin A on muscle sugar transport has not hitherto been reported. Cuatrecasas [31] has suggested that the insulin-like actions of concanavalin $\mathrm{A}$ in the adipocyte could result from the binding of the lectin to the insulin receptor, thereby triggering an 'insulin' signal. If this were so, it could be expected that the effect of the lectin would be depressed by denervation. The ability of concanavalin A to stimulate sugar transport in denervated muscle suggests that its action could be triggered through some other mechanism.

The second point which arises from the results shown in Table 2 concerns the actions of diamide, hydrogen peroxide and vitamin $\mathrm{K}_{5}$. These are members of a group of oxidants which have been shown to stimulate sugar transport in adipocytes [21]. Sorensen et al. [32] have reported that hydrogen peroxide stimulates sugar transport in rat soleus muscle. Apart from this and the results reported in this paper, the effect of oxidants on muscle sugar transport has not otherwise been studied. According to Czech [20], these agents all activate sugar transport in the adipocyte because of their ability to oxidize some essential sulphydryl group(s). It is surprising that denervation inhibits the stimulatory effect of diamide on muscle sugar transport, but does not affect the action of hydrogen peroxide and vita$\min \mathrm{K}_{5}$. If, as has been assumed, the stimulatory effect of all these oxidants involved the same metabolic step, 
then it seems reasonable to expect that all should have been affected similarly by denervation. The anomalous behaviour of diamide in this respect suggests that its effect on sugar transport is mediated separately from and prior to the effects of hydrogen peroxide and vitamin $\mathrm{K}_{5}$. Beyond the simple observation that diamide stimulates sugar transport in the adipocyte, the underlying mechanism of action of this agent has not been further explored. These studies have shown that the action of diamide differs from that of the other oxidants; the precise nature of the action of diamide and the other oxidants remains to be determined.

Acknowledgements. We wish to thank Dr. J.H. Aylward for his advice on the assay of glycogen synthase and Dr. K.T. Yu for assistance with the insulin-sensitivity experiments. This work was supported in part by a Special Research Grant from Monash University.

\section{References}

1. Kahn CR (1976) Membrane receptors for hormones and neurotransmitters. J Cell Biol 70: 261-286

2. Czech MP (1981) Insulin action. Am J Med 70:142-150

3. Karnieli E, Zarnowski MJ, Hissin PJ, Simpson IA, Salans LB, Cushman SW (1981) Insulin-stimulated translocation of glucose transport systems in the isolated rat adipose cell. Time course, reversal, insulin concentration dependency, and relationship to glucose transport activity. J Biol Chem 256: 4772-4777

4. Kono T, Suzuki K, Dansey LE, Robinson FW, Blevins TL (1981) Energy-dependent and protein-synthesis-independent recycling of the insulin-sensitive glucose transport mechanism in fat cells. $J$ Biol Chem 256: 6400-6407

5. Cheng K, Galasko G, Huang L, Kellogg J, Larner J (1980) Studies on the insulin mediator. II Separation of two antagonistic biologically active materials from fraction II. Diabetes 29:659-661

6. Kiechle FL, Jarett L, Kotagal N, Popp DA (1981) Partial purification from rat adipocyte plasma membranes of a chemical mediator which simulates the action of insulin on pyruvate dehydrogenase. J Biol Chem 256: 2945-2951

7. Seals JR, Czech MP (1981) Characterization of a pyruvate dehydrogenase activator released by adipocyte plasma membranes in response to insulin. J Biol Chem 256: 2894-2899

8. Buse MG, Buse J (1959) Glucose uptake and response to insulin of the isolated rat diaphragm. The effect of denervation. Diabetes 8: 218-225

9. Buse MG, Buse J (1961) The effect of denervation and insulin on the penetration of D-xylose into rat hemidiaphragms. Diabetes 10: 134-141

10. Korbl GP, Sloan IG, Gould MK (1977) Effect of anoxia, 2,4-dinitrophenol and salicylate on xylose transport by isolated rat soleus muscle. Biochim Biophys Acta 465: 93-109

11. Greenwood FC, Hunter WM, Glover JS (1963) The preparation of ${ }^{131}$ I-labelled human growth hormone of high specific radioactivity. Biochem J 89: 114-123

12. Yu KT, Gould MK (1978) Effect of prolonged anaerobiosis on ${ }^{125} \mathrm{I}$-insulin binding to rat soleus muscle: permissive effect of ATP. Am J Physiol 235: E606-E613

13. Bradford MM (1976) A rapid and sensitive method for the quantitation of microgram quantities of protein utilizing the principle of protein-dye binding. Anal Biochem 72: 248-254

14. Thomas JA, Schlender KK, Larner J (1968) A rapid filter paper assay for UDP glucosemglycogen glycosyltransferase, including an improved biosynthesis of UDP ${ }^{14} \mathrm{C}-\mathrm{gl}$ lucose. Anal Biochem 25: 486-499
15. Buse MG, McMaster J, Buse J (1965) The effect of denervation and insulin on protein synthesis in the isolated rat diaphragm. Metabolism 14: 1220-1232

16. Bombora $\mathrm{G}$, Bergamini $\mathrm{E}$ (1968) $\alpha$-aminoisobutyric acid uptake in vitro by the rat extensor digitorum longus muscle after denervation and tenotomy. Biochim Biophys Acta 150:226-236

17. Czech MP, Lynn WS (1973) Stimulation of glucose metabolism by lectins in isolated white fat cells. Biochim Biophys Acta 297: 368-377

18. Czech MP, Lawrence JC, Lynn WS (1974) Activation of hexose transport by concanavalin A in isolated brown fat cells. Effects of cell surface modification with neuraminidase and trypsin on lectin and insulin action. J Biol Chem 249: 7499-7505

19. Cuatrecasas P, Tell GPE (1973) Insulin-like activity of concanavalin $A$ and wheat germ agglutinin - direct interactions with insulin receptors. Proc Natl Acad Sci USA 70: 485-489

20. Czech MP (1976) Current status of the thiol redox model for the regulation of hexose transport by insulin. J Cell Physiol 89: 661-668

21. Czech MP (1976) Regulation of the D-glucose transport system in isolated fat cells. Mol Cell Biochem 11: 51-63

22. Yu KT, Gould MK (1981) Stimulation of sugar transport in rat soleus muscle by prolonged cooling at $0^{\circ} \mathrm{C}$. Diabetologia 21: 482-488

23. Forsayeth J, Gould MK (1981) Effects of hyperosmolarity on basal and insulin-stimulated muscle sugar transport. Am J Physiol 240: E263-E267

24. Yu KT, Keo L, Gould MK (1980) Stimulatory and inhibitory effects of EDTA on sugar transport by rat soleus muscle. Cell Calcium $1: 337-347$

25. Lipman RL, Raskin P, Love T, Triebwasser J, Lecocq FR, Schnure JJ (1972) Glucose intolerance during decreased physical activity in man. Diabetes 21: 101-107

26. Duckworth WC, Solomon SS, Jallepalli P, Heckemeyer C, Finnern J, Powers A (1980) Glucose intolerance due to insulin resistance in patients with spinal cord injuries. Diabetes 29:906-910

27. Berger M, Kemmer FW, Becker K, Herberg L, Schwenen M, Gjinavci A, Berchtold P (1979) Effect of physical training on glucose tolerance and on glucose metabolism of skeletal muscle in anaesthetized normal rats. Diabetologia 16: 179-184

28. Sovik O (1965) Effect of insulin on the isolated rat diaphragm in the presence and in the absence of puromycin and actinomycin $D$. Acta Physiol Scand 63:325-335

29. Eboue-Bonis D, Chambaut AM, Volfin P, Clauser H (1967) Action selective de la $\mathrm{N}$-ethylmaleimide sur la stimulation per insuline du metabolisme du diaphragme en survie. Bull Soc Chim Biol 49: $415-431$

30. Tsuda M, Taketomi S, Iwatsuka H (1980) Selective inhibition by neuraminidase of insulin action on hexose metabolism of mouse adipocytes. Am J Physiol 239: E186-E191

31. Cuatrecasas P (1973) Interaction of concanavalin A and wheat germ agglutinin with the insulin receptor of fat cells and liver. $J$ Biol Chem 248: 3528-3534

32. Sorensen SS, Christensen F, Clausen T (1980) The relationship between the transport of glucose and cations across cell membranes in isolated tissues. X. Effect of glucose transport stimuli on the efflux of isotopically labelled calcium and 3-O-methylglucose from soleus muscles and epididymal fat pads of the rat. Biochim Biophys Acta 602: 433-445

Received: 1 September 1981

and in revised form: 5 August 1982

Dr. M. K. Gould

Department of Biochemistry

Monash University

Clayton, Victoria 3168

Australia 